\title{
SALINE STRESS ONTO GROWTH AND PHYSIOLOGY OF TRIFOLIATE CITRUS HYBRIDS DURING ROOTSTOCK FORMATION
}

\author{
ESTRESSE SALINO NO CRESCIMENTO E FISIOLOGIA DE HÍBRIDOS \\ TRIFOLIADOS DE CITROS ENQUANTO PORTA-ENXERTOS
}

\section{Marcos Eric Barbosa BRITO ${ }^{1}$; Francisco Vaniés da Silva SÁ $^{2}$; Luderlândio de Andrade SILVA²; Walter dos Santos SOARES FILHO ${ }^{3}$; Hans Raj GHEYI ${ }^{4}$; Rômulo Carantino Lucena MOREIRA ${ }^{2}$; Pedro Dantas FERNANDES ${ }^{5}$; Lizaiane Cardoso de FIGUEIREDO ${ }^{6}$}

1. Bolsista PQ do CNPq, Professor, Doutor, Universidade Federal de Sergipe, Campus do Sertão; Nossa Senhora da Glória, SE, Brasil. marcoseric@pq.cnpq.br; 2. Doutorando em Engenharia Agrícola, Universidade Federal de Campina Grande - UFCG, Campina Grande,

PB, Brasil; 3. Pesquisador A da Embrapa Mandioca e Fruticultura, Cruz das Almas, BA, Brasil; 4. Professor Visitante, Doutor, Universidade Federal do Recôncavo Baiano - UFRB, Cruz das Almas, BA, Brasil; 5. Professor, Doutor, UFCG, Campina Grande, PB, Brasil; 6. Mestranda em Horticultura Tropical, UFCG, Pombal, PB, Brasil.

\begin{abstract}
High salts concentrations in soil and water are common in semi-arid regions, which reduces the growth and development of crops, especially sensitive plants, such as citrus, being important to identify tolerant materials as well as to study the physiology of these plants. An experiment was conducted evaluate the growth and physiology of citrus trifoliate citrus hybris during their early stage of development (seedling stage) under salt stress conditions. These hydrids were obtained through the Citrus Breeding Program of Embrapa Cassava \& Fruits consisting of 'Common sunki' mandarin x 'Argentina' citrange - 019, 'Common sunki' mandarin x ('Rangpur' lime x Poncirus trifoliata) - 040, Trifoliate hybrids - 069, 116 and 127, distributed in a randomized block design with three replications. Nucellar seedlings of the genotypes were grown in an hydroponic system using Leonard jars. The application of nutrient solution with saline water started 90 days after sowing, extending to 120 days, when the seedlings were evaluated for plant growth and physiology. The genotypes common 'Sunki' mandarin x 'Argentina' citrange - 019, Common 'Sunki' mandarin $\mathrm{x}$ ('Rangpur' lime x P. trifoliata) - 040 and Trifoliate hybrid - 069 showed the greater tolerance to salinity, while the Trifoliate hybrid - 116 and 127 were found to be the less tolerant.
\end{abstract}

KEYWORDS: Citrus spp. Chlorophyll fluorescence. Salinity.

\section{INTRODUCTION}

In semiarid regions, such as in northeastern Brazil, problems with irrigation water quality, rainfall limitations and irregularity of in its distribution are frequent (AYERS; WESTCOT, 1985). Such conditions tend to favor soil salinization, as evapotranspiration in these regions is higher than precipitation (QADIR et al., 2007).

Thus, in order to cultivate fruit species, such as citrus, in the semiarid region of northeastern Brazil, which are considered prone to salinity, it is necessary to use genotypes with greater tolerance to salinity (SINGH et al., 2003). Tolerance to salinity varies among species, genotypes and even with crop development stages (AYERS; WESTCOT, 1985). Salt stress can cause growth reduction due to induced drought, specific ion toxicity, ionic imbalance or a combination of these factors (HUSSAIN et al., 2012; SYVERTSEN; GARCIASANCHEZ, 2014; HUSSAIN et al., 2015). However, the capacity of citrus plants to maintain satisfactory growth under limiting factors, such as salinity, varies among species, planting systems, development stage, age and climatic conditions, which affect absorption and water transport, stomatal opening and transpiration (RODRIGUEZGAMIR et al., 2012; GONZÁLEZ et al., 2012).

Citrus cultivation can be limited by water and/or soil salinity. Thus, it is important to obtain genotypes with higher tolerance potential, as citrus growth can be negatively affected by irrigation with saline water (BRITO et al., 2014). These authors also verified that some genotypes have a high salt tolerance potential. Thus, there is a need to find tolerant genotypes in order to expand citrus cultivation in salt-affected areas in northeastern Brazil. In the same line, to begin the process of genotypes screening, it is necessary to study the salinity tolerance in all phases of the citrus crop system, including rootstocks formation.

In this context, Silva et al. (2014) studying physiological mechanisms in Trifoliate hybrid citrus and hybrid tangerine 'Sunki', all recommended as rootstocks, based indications of tolerant materials, especially rootstocks, by checking the changes in gas exchange and chlorophyll fluorescence and Brito et al. (2016), in similar research, but studying 
citrus varieties, also identified tolerant genotypes, like Rangpur lime and Volkamer lemon, using gas exchange and chlorophyll fluorescence, observing relative reductions in assimilation rate and in the growth of citrus plants under salt stress.

The objective of present study was to evaluate the growth and physiology of citrus hybrids under saline stress conditions.

\section{MATERIAL AND METHODS}

The experiment was conducted from March to July 2013 in a greenhouse of the Center of Agrifood Science and Technology - CCTA, Federal University of Campina Grande - UFCG, Pombal, PB (647'20"S Latitude and 3748'01"W Longitude and altitude of $184 \mathrm{~m}$ ).

\section{Treatments and experimental design}

The treatments were arranged in a factorial scheme, 2 x 5, and distributed in a randomized block design, with three replications, with four plants/pot per plot. Randomized block design was choosen in order to minimize the effect due to difference in radiation incidence inside the protected environment.

The first factor was related to two levels of salt concentration in the solution, nutrient solution of low salt concentration, which had a final electrical conductivity (EC) of $2.6 \mathrm{dS} \mathrm{m} \mathrm{m}^{-1}$, prepared using the local supply water (EC of $0.3 \mathrm{dS} \mathrm{m}^{-1}$ ); and the other corresponded to the solution of high salt concentration (final EC of $6.3 \mathrm{dS} \mathrm{m}^{-1}$ ), prepared by addition of salts of $\mathrm{NaCl}, \mathrm{CaCl}_{2} .2 \mathrm{H}_{2} \mathrm{O}$ and $\mathrm{MgCl}_{2} \cdot 6 \mathrm{H}_{2} \mathrm{O}$ salts to local supply water, maintaining an equivalent ratio of 7:2: 1 among $\mathrm{Na}, \mathrm{Ca}$ and $\mathrm{Mg}$, respectively. During experimentatal period, solutions were monitored weekly using portable $\mathrm{pH}$ and conductivity meter.

The solutions were applied on five citrus hybrids, with potential for use as rootstock, obtained by the Citrus Breeding Program of Embrapa
Cassava \& Fruits (CBP): 1. 'Common sunki' mandarin [Citrus sunki (Hayata) hort. ex Tanaka] $\mathrm{x}$ 'Argentina' citrange [C. sinensis (L.) Osbeck $\mathrm{x}$ Poncirus trifoliata (L.) Raf.] - 019 (CSM x ARGC 019), 2. CSM x ('Rangpur' lime C. limonia Osbeck x P. trifoliata) - 040 [CSM x (RL x PT) - 040], 3. Trifoliate hybrid - 069 (TH - 069), 4. TH - 116 and 5. TH - 127 (resulting from crossing between Citrus spp. x $P$. trifoliata or hybrids of this species).

With regard to salinity levels, the water with $0.3 \mathrm{dS} \mathrm{m}^{-1}$ was the local supply water, and the water with $4.0 \mathrm{dS} \mathrm{m}^{-1}$ was chosen based on salinity threshold for citrus plants according to Maas (1993) and the fact that this salinity level is common in water from deep wells in Brazilian semiarid region (MEDEIROS et al., 2003).

The rootstock formation phase was chosen because it is the initial phase of the citrus production system, using plants from the crossing between the Sunki mandarin and trifoliate hybrids, which can generate plants with potential tolerance to biotic and abiotic stresses (SILVA et al., 2014; SÁ et al., 2015). However, it is necessary to study other stages of the citrus production system (BRITO et al., 2015; PEREZ; PEREZ, 2015).

\section{Experimental conditions}

Sowing and growing of nucellar seedlings of each hybrid was undertaken in pots with $1.5 \mathrm{~L}$ capacity. Coconut fiber previously washed with water was used as substrate to ensure the absence of salt in the material. Nutrient solution (Table 1) recommended by Hoagland; Arnon (1950) was used after adaptation, to meet the nutritional needs of the genotypes, based on preliminary tests.

Regarding screening of nucellar seedlings from genotypes, before the experiment, all genotypes were evaluated about polyembryony degrees, obtaining values higher that $80 \%$, it improved the confiability in the visual screening by an expert.

Table 1. Concentration of nutrients in the nutrient solution of low and high salinity used in hydroponic system

\begin{tabular}{|c|c|c|c|c|c|c|c|c|c|c|c|c|c|}
\hline \multicolumn{14}{|c|}{ Nutrient solution $^{*}$} \\
\hline $\mathrm{N}$ & $\mathrm{P}$ & $\mathrm{K}$ & $\mathrm{Ca}$ & $\mathrm{Mg}$ & $\mathrm{Na}$ & $S$ & $\mathrm{Fe}^{* *}$ & $\mathrm{Mn}$ & $\mathrm{B}$ & $\mathrm{Cu}$ & $\mathrm{Zn}$ & Mo & $\mathrm{CE}$ \\
\hline & & & & & & & & & $(\mathrm{mm}$ & $l_{\mathrm{c}} \mathrm{L}^{-}$ & & & $\mathrm{dS} \mathrm{m}^{-1}$ \\
\hline 15 & 1 & 6 & 5 & 2 & - & 2 & 0.0625 & 0.01 & 0.05 & 0.003 & 0.0008 & 0.001 & 2.3 \\
\hline \multicolumn{14}{|c|}{ Low salinity solution (S1) } \\
\hline 15 & 1 & 6.3 & 5.2 & 2.6 & 1.4 & 2.067 & 0.0625 & 0.01 & 0.05 & 0.003 & 0.0008 & 0.001 & 2.6 \\
\hline \multicolumn{14}{|c|}{ High salinity solution (S2) } \\
\hline 15 & 1 & 6.3 & 12.6 & 6.3 & 27.3 & 2.067 & 0.0625 & 0.01 & 0.05 & 0.003 & 0.0008 & 0.001 & 6.3 \\
\hline
\end{tabular}


Nucellar seedlings were cultivated in Leonard pots fitted with PET bottles, as described by Silva et al. (2014). The upper part of the pot was filled with $1.5 \mathrm{~L}$ of the substrate and the lower part with Hoagland ${ }^{\circledR}$ nutrient solution (HOAGLAND; ARNON, 1950) under continuous flow.

After preparation of the pots, they were covered with double sided plastic in order to reduce evaporation losses. Solution volume was checked daily and, when necessary, supplemented according to the treatment, ensuring that the moisture content in substrate remained close to the maximum retention capacity.

Direct sowing was conducted in Leonard pots and thinning was carried out when the seedlings had three or more leaves, leaving only one nucellar plant per pot.

Pest control, monitoring and prevention was performed according to the recommendations for the production of citrus seedlings.

\section{Plant mensurements}

According to the methodology proposed by Benincasa (2003), absolute growth rate (equation 1) and relative growth rate (equation 2) were determined from the measurements taken for plant height, stem diameter and number of leaves, respectively, of the genotypes at two stages, the first was at 90 days after sowing (DAS), and the second was realized 30 days after saline treatments, corresponding to 120 DAS when the genotypes had diameters between 0.4 and $0.6 \mathrm{~cm}$.

$$
\begin{aligned}
\text { AGR } & =\frac{x^{2}-x^{1}}{\mathrm{t}^{2}-\mathrm{t} 1} \\
\mathrm{RGR} & =\frac{\ln x^{2}-\ln x 1}{\mathrm{t} 2-\mathrm{t} 1}
\end{aligned}
$$

where $\mathrm{AGR}=$ absolute growth rate; $\mathrm{x} 1=$ measurement at time $\mathrm{t} 1 ; \mathrm{x} 2=$ measurement at time $\mathrm{t} 2 ; \mathrm{RGR}=$ relative growth rate; $\mathrm{ln}=$ natural logarithm.

Further, at 120 DAS, citrus genotypes were also evaluated for physiological behaviour under salt stress, measuring $\mathrm{CO}_{2}$ assimilation rate $\left(A, \mathrm{CO}_{2}\right.$ $\left.\mu \mathrm{mol} \mathrm{m} \mathrm{s}^{-2}\right)$, transpiration $\left(E, \mathrm{H}_{2} \mathrm{O} \mathrm{mmol} \mathrm{m} \mathrm{s}^{-1}\right)$, stomatal conductance $\left(g s, \mathrm{H}_{2} \mathrm{O} \mathrm{mol} \mathrm{m} \mathrm{m}^{-2}\right)$ and substomatal $\mathrm{CO}_{2}\left(\mathrm{Ci}, \mu \mathrm{mol} \mathrm{mol}{ }^{-1}\right)$ in an intermediate leaf, between 7 and 9 hours, with $\mathrm{CO}_{2}$ entrance from atmosphere under ambient temperature and air humidity, using the "LCPro+" portable photosynthesis measuring equipment, ADC BioScientific Ltd. With these data, intrinsic water use efficiency (iWUE) $(A / E)\left[\left(\mathrm{CO}_{2} \mu \mathrm{mol} \mathrm{m} \mathrm{m}^{-2} \mathrm{~s}^{-1}\right)\right.$ $\left.\left(\mathrm{H}_{2} \mathrm{O} \text { mmol } \mathrm{m}^{-2} \mathrm{~s}^{-1}\right)^{-1}\right]$ and instantaneous carboxylation efficiency $(\mathrm{A} / \mathrm{Ci})$ were quantified (Brito et al., 2012). On the same leaf on which gas exchanges were analysed, leaf tweezers were placed and, after a 30 min dark-adaptation period, the following data were determined: initial fluorescence (Fo), maximum fluorescence (Fm), variable fluorescence (Fm-Fo) and photosystem II quantum efficiency (Fv/Fm) (Silva et al., 2014), using the PEA - Hansatech equipment.

After measurement of physiological variables, plant samples were collected to determine dry matter of shoot, root and total. For this purpose, the different plant parts were placed in an oven regulated at $65^{\circ} \mathrm{C}$, for $72 \mathrm{~h}$ and then weighed on an analytical scale. Root/shoot ratio was assessed from these data through the quotient between dry matter of root and shoot.

\section{Statistical analysis}

Data were submitted to F test (ANOVA). In case of significant effect, Scott Knott's mean grouping test at a probability level of 0.05 was used for genotype factor, and the mean test $(\mathrm{t})$ was used for salinity factor for hybrids (FERREIRA, 2011).

\section{RESULTS}

\section{Plant growth}

For the nucellar seedling hybrids, the highest absolute and relative height growth rates were observed in the genotypes CSM x ARGC - 019 and CSM x (RL x PT) - 040, when seedlings were grown in the high salinity solution (S2) (Table 2). Lowest growth rates were observed for $\mathrm{TH}$ genotypes, except for the $\mathrm{TH}-127$ which presented the highest value when grown in nutrient solution prepared with low salinity water (Table 2).

The citrus genotypes responded differently to salinity levels. In terms of growth rates, varying responses of the citrus genotypes to salinity levels were observed, with reductions in the absolute growth rate in height of $31.0 \%$ and $21.4 \%$ in CSM x ARGC - 019 and TH - 127 genotypes, respectively. The opposite was observed in CSM x (RL x PT) 040 and TH - 116 genotypes, where the higher height growth rates were observed in the solution with higher electrical conductivity, with values of around $31.0 \%$ and $88.6 \%$, respectively (Table 2 ).

Regarding stem diameter growth rates, the largest absolute and relative growth rates were observed in solutions with increased salt levels for the hybrid CSM x (RL x PT) - 040 (Table 2). On the other hand, highest reductions in the diameter growth rate were observed in the genotypes $\mathrm{TH}$ 127 and $\mathrm{TH}-069$ (Table 2), 41.7\% and 71.4\%, respectively. 
Table 2. Absolute and relative growth rates in height (AGRH, RGRH), stem diameter (AGRSD, RGRSD), number of leaves (AGRNL, RGRNL) for different citrus genotypes grown in two levels of water salinity.

\begin{tabular}{|c|c|c|c|c|}
\hline \multirow{3}{*}{ Genotypes } & \multicolumn{4}{|c|}{ Water salinity $\left(\mathrm{dS} \mathrm{m}^{-1}\right)$} \\
\hline & $\mathrm{S} 1\left(2.6 \mathrm{dS} \mathrm{m}^{-1}\right)$ & $\mathrm{S} 2\left(6.3 \mathrm{dS} \mathrm{m}^{-1}\right)$ & $\mathrm{S} 1\left(2.6 \mathrm{dS} \mathrm{m}^{-1}\right)$ & $\mathrm{S} 2\left(6.3 \mathrm{dS} \mathrm{m}^{-1}\right)$ \\
\hline & \multicolumn{2}{|c|}{$\mathrm{AGRH}^{*}$} & \multicolumn{2}{|c|}{ RGRH* } \\
\hline CSM x ARGC - 019 & $0.392 \mathrm{aA}$ & $0.308 \mathrm{aB}$ & $0.023 \mathrm{aA}$ & $0.024 \mathrm{aA}$ \\
\hline CSM x (RL x PT) -040 & $0.175 b B$ & $0.229 \mathrm{bA}$ & $0.017 \mathrm{bB}$ & $0.028 \mathrm{aA}$ \\
\hline TH - 069 & $0.075 \mathrm{cA}$ & $0.056 \mathrm{dA}$ & $0.007 \mathrm{cA}$ & $0.007 \mathrm{dA}$ \\
\hline TH - 116 & $0.044 \mathrm{cA}$ & $0.083 \mathrm{dA}$ & $0.008 \mathrm{cB}$ & $0.012 \mathrm{cA}$ \\
\hline \multirow[t]{2}{*}{$\mathrm{TH}-127$} & $0.200 \mathrm{bA}$ & $0.138 \mathrm{cB}$ & $0.025 \mathrm{aA}$ & $0.018 \mathrm{cB}$ \\
\hline & \multicolumn{2}{|c|}{ AGRSD* } & \multicolumn{2}{|c|}{ RGRSD* } \\
\hline CSM x ARGC - 019 & $0.043 \mathrm{aA}$ & $0.031 \mathrm{bB}$ & $0.015 \mathrm{aA}$ & $0.013 \mathrm{bA}$ \\
\hline CSM $x($ RL $x$ PT $)-040$ & $0.022 \mathrm{bB}$ & $0.042 \mathrm{aA}$ & $0.009 \mathrm{bB}$ & $0.021 \mathrm{aA}$ \\
\hline TH - 069 & $0.018 \mathrm{bA}$ & $0.004 \mathrm{cB}$ & $0.007 \mathrm{bA}$ & $0.002 \mathrm{~dB}$ \\
\hline TH - 116 & $0.018 \mathrm{bA}$ & $0.023 \mathrm{bA}$ & $0.010 \mathrm{bA}$ & $0.012 \mathrm{bA}$ \\
\hline \multirow[t]{2}{*}{ TH - 127} & $0.024 \mathrm{bA}$ & $0.011 \mathrm{cB}$ & $0.012 \mathrm{aA}$ & $0.007 \mathrm{cB}$ \\
\hline & \multicolumn{2}{|c|}{ AGRNL* } & \multicolumn{2}{|c|}{ RGRNL* } \\
\hline CSM x ARGC - 019 & $0.369 \mathrm{aA}$ & $0.275 \mathrm{aB}$ & $0.023 \mathrm{aA}$ & $0.020 \mathrm{aA}$ \\
\hline CSM x (RL x PT) -040 & $0.183 \mathrm{bA}$ & $0.175 \mathrm{bA}$ & $0.016 \mathrm{bB}$ & $0.022 \mathrm{aA}$ \\
\hline TH - 069 & $0.017 \mathrm{cA}$ & $0.025 \mathrm{dA}$ & $0.002 \mathrm{dA}$ & $0.002 \mathrm{cA}$ \\
\hline TH - 116 & $0.019 \mathrm{cB}$ & $0.178 \mathrm{bA}$ & $0.009 \mathrm{cB}$ & $0.020 \mathrm{aA}$ \\
\hline TH - 127 & $0.183 \mathrm{bA}$ & $0.092 \mathrm{bB}$ & $0.018 \mathrm{bA}$ & $0.009 \mathrm{bB}$ \\
\hline
\end{tabular}

$*$ and $* *=$ significant at 0.05 and 0.01 probability level, respectively. Means followed by different small letters indicate the difference between rootstocks by Skott Knott test and different capital letters indicate the difference between salinity levels by $\mathrm{F}$ test at 0.05 probability level. Genotypes: CSM = common 'Sunki' mandarin [Citrus sunki (Hayata) hort. ex Tanaka]; ARGC = 'Argentina' citrange [C. sinensis (L.) Osbeck x Poncirus trifoliata (L.) Raf.]; RL = 'Rangpur' lime C. limonia Osbeck; PT = Poncirus trifoliate; TH = Trifoliate hybrid.

For absolute and relative growth rates of the number of leaves, a similar response to the growth in height and stem diameter was observed, and the genotype CSM x ARGC - 019 showed the highest rates. However, in relation to the genotypes CSM $x$ (RL x PT) - 040 and TH-116, there was an increase in growth rates of the number of leaves when subjected to the high salinity solution (Table 2).

\section{Gas exchange}

The stomatal conductance of citrus genotypes was not significantly affected by salinity levels. However, there was a significant difference among the genotypes, and highest stomatal conductance was observed in the genotype TH - 069 (Table 3). A similar trend was observed for plant transpiration and intrinsic water use efficiency, with better results observed in genotype $\mathrm{TH}-069$, with greatest values (Table 3).

The high salinity of nutrient solution promoted changes in the $\mathrm{CO}_{2}$ internal concentration of the genotype $\mathrm{TH}-116$ (Table 2), being observed an increase of $14 \%$ in $\mathrm{CO}_{2}$ internal concentration when the plants were grown under higher salinity solution $\left(4,0 \mathrm{dS} \mathrm{m}^{-1}\right)$ compared to the low salinity solution (Table 3). For other genotypes the high salinity solution did not cause significant differences, but the higher mean was observed on genotype HTR - 127, and the smaller in the HTR 069 under saline solutions.

In terms of $\mathrm{CO}_{2}$ assimilation rate, only the hybrid CSM x ARGC - 019 showed changes when subjected to different salinity levels, expanding its $\mathrm{CO}_{2}$ assimilation by $45.1 \%$ at the $\mathrm{EC}=4.0 \mathrm{dS} \mathrm{m}{ }^{-1}$ level compared to the $0.3 \mathrm{dS} \mathrm{m}^{-1}$ level (Table 3).

\section{Chlorophyll fluorescence}

Studying parameters about chlorophyll fluorescence in citrus hybrid rootstocks, it is noted that only CSM x (RL x PT) - 040 was influenced by salinity from data of initial and maximum fluorescence (Table 4), observing increases of $37.0 \%$ and $32.1 \%$, respectively, in plants under higher salinity after 30 days of application of treatment. 
Table 3. Stomatal conductance ( $g s)$, transpiration $(E)$, water use efficiency (WUE), $\mathrm{CO}_{2}$ internal concentration $(\mathrm{Ci}), \mathrm{CO}_{2}$ assimilation $(\mathrm{A})$ and carboxylation instantaneous efficiency $(\mathrm{A} / \mathrm{Ci})$ for different citrus genotypes grown in two levels of water salinity.

\begin{tabular}{|c|c|c|c|c|}
\hline \multirow{2}{*}{ Genotypes } & \multicolumn{4}{|c|}{ Water salinity $\left(\mathrm{dS} \mathrm{m}^{-1}\right)$} \\
\hline & $\mathrm{S} 1\left(2.6 \mathrm{dS} \mathrm{m}^{-1}\right)$ & $\mathrm{S} 2\left(6.3 \mathrm{dS} \mathrm{m}^{-1}\right)$ & $\mathrm{S} 1\left(2.6 \mathrm{dS} \mathrm{m}^{-1}\right)$ & $\mathrm{S} 2\left(6.3 \mathrm{dS} \mathrm{m}^{-1}\right)$ \\
\hline & \multicolumn{2}{|c|}{$g s^{* *}$} & \multicolumn{2}{|c|}{$E^{* *}$} \\
\hline CSM x ARGC - 019 & \multicolumn{2}{|c|}{$0.13 \mathrm{~b}$} & \multicolumn{2}{|c|}{$2.05 \mathrm{~b}$} \\
\hline CSM x (RL x PT) -040 & \multicolumn{2}{|c|}{$0.11 \mathrm{~b}$} & \multicolumn{2}{|c|}{$2.04 \mathrm{~b}$} \\
\hline TH - 069 & \multicolumn{2}{|c|}{$0.18 \mathrm{a}$} & \multicolumn{2}{|c|}{$2.77 \mathrm{a}$} \\
\hline TH - 116 & \multicolumn{2}{|c|}{$0.12 \mathrm{~b}$} & \multicolumn{2}{|c|}{$2.01 \mathrm{~b}$} \\
\hline $\mathrm{TH}-127$ & \multicolumn{2}{|c|}{$0.09 \mathrm{~b}$} & \multicolumn{2}{|c|}{$1.62 \mathrm{~b}$} \\
\hline & \multicolumn{2}{|c|}{$W U E^{* * *}$} & \multicolumn{2}{|c|}{$C i^{*}$} \\
\hline CSM x ARGC - 019 & \multicolumn{2}{|c|}{$3.27 \mathrm{a}$} & $262 \mathrm{bA}$ & $249 \mathrm{bA}$ \\
\hline CSM x (RL x PT) -040 & \multicolumn{2}{|c|}{$2.58 \mathrm{~b}$} & $263 \mathrm{bA}$ & $261 \mathrm{aA}$ \\
\hline TH - 069 & \multicolumn{2}{|c|}{$3.61 \mathrm{a}$} & $245 \mathrm{bA}$ & $232 \mathrm{bA}$ \\
\hline TH - 116 & \multicolumn{2}{|c|}{$2.99 \mathrm{~b}$} & $246 \mathrm{bB}$ & $286 \mathrm{aA}$ \\
\hline \multirow[t]{2}{*}{ TH - 127} & \multicolumn{2}{|c|}{$2.98 \mathrm{~b}$} & $312 \mathrm{aA}$ & $271 \mathrm{aA}$ \\
\hline & \multicolumn{2}{|c|}{$A^{*}$} & \multicolumn{2}{|c|}{$A / C i^{*}$} \\
\hline CSM x ARGC - 019 & $5.54 \mathrm{bB}$ & $8.04 \mathrm{bA}$ & $0.021 \mathrm{cB}$ & $0.033 \mathrm{bA}$ \\
\hline CSM x (RL x PT) -040 & $4.16 \mathrm{cA}$ & $5.70 \mathrm{cA}$ & $0.017 \mathrm{cA}$ & $0.022 \mathrm{cA}$ \\
\hline TH - 069 & $9.46 \mathrm{aA}$ & $10.41 \mathrm{aA}$ & $0.039 \mathrm{aA}$ & $0.045 \mathrm{aA}$ \\
\hline TH - 116 & $6.72 \mathrm{bA}$ & $5.11 \mathrm{cA}$ & $0.028 \mathrm{bA}$ & $0.018 \mathrm{cB}$ \\
\hline TH - 127 & $4.15 \mathrm{cA}$ & $4.86 \mathrm{cA}$ & $0.013 \mathrm{cA}$ & $0.018 \mathrm{cA}$ \\
\hline
\end{tabular}

$*$ and $* *=$ significant at 0.05 and 0.01 probability level, respectively. Means followed by different small letters indicate the difference between rootstocks by Skott Knott test and different capital letters indicate the difference between salinity levels by $\mathrm{F}$ test at 0.05 probability level. Genotypes: CSM = common 'Sunki' mandarin [Citrus sunki (Hayata) hort. ex Tanaka]; ARGC = 'Argentina' citrange [C. sinensis (L.) Osbeck x Poncirus trifoliata (L.) Raf.]; RL = 'Rangpur' lime C. limonia Osbeck; PT = Poncirus trifoliate; $\mathrm{TH}=$ Trifoliate hybrid.

Table 4. Initial fluorescence (Fo), maximum fluorescence (Fm), variable fluorescence (Fm-Fo), photosystem II quantum efficiency $(\mathrm{Fv} / \mathrm{Fm})$ for different citrus genotypes grown in two levels of water salinity.

\begin{tabular}{|c|c|c|c|c|}
\hline \multirow{3}{*}{ Genotypes } & \multicolumn{4}{|c|}{ Water salinity $\left(\mathrm{dS} \mathrm{m}^{-1}\right)$} \\
\hline & $\mathrm{S} 1\left(2.6 \mathrm{dS} \mathrm{m}^{-1}\right)$ & $\mathrm{S} 2\left(6.3 \mathrm{dS} \mathrm{m}^{-1}\right)$ & $\mathrm{S} 1\left(2.6 \mathrm{dS} \mathrm{m}^{-1}\right)$ & $\mathrm{S} 2\left(6.3 \mathrm{dS} \mathrm{m}^{-1}\right)$ \\
\hline & \multicolumn{2}{|c|}{$\mathrm{Fo}^{*}$} & \multicolumn{2}{|c|}{ Fm* } \\
\hline CSM x ARGC - 019 & $513 \mathrm{aA}$ & $512 \mathrm{aA}$ & $2578 \mathrm{aA}$ & $2462 \mathrm{aA}$ \\
\hline CSM x (RL x PT $)-040$ & $340 \mathrm{~dB}$ & $466 \mathrm{aA}$ & $1570 \mathrm{cB}$ & $2075 \mathrm{bA}$ \\
\hline $\mathrm{TH}-069$ & $402 \mathrm{cA}$ & $427 \mathrm{aA}$ & 1944 bA & $1820 \mathrm{bA}$ \\
\hline $\mathrm{TH}-116$ & $439 \mathrm{bA}$ & $460 \mathrm{aA}$ & 1949 bA & $2023 \mathrm{bA}$ \\
\hline \multirow[t]{2}{*}{$\mathrm{TH}-127$} & $437 \mathrm{bA}$ & $486 \mathrm{aA}$ & $2133 \mathrm{bA}$ & $2209 \mathrm{aA}$ \\
\hline & \multicolumn{2}{|c|}{$\mathrm{Fm}-\mathrm{Fo}^{* *} *$} & \multicolumn{2}{|c|}{$\mathrm{Fv} / \mathrm{Fm}^{* * *}$} \\
\hline CSM x ARGC - 019 & \multicolumn{2}{|c|}{$1419 \mathrm{c}$} & & \\
\hline $\operatorname{CSM} \times(\mathrm{RL} \times \mathrm{PT})-040$ & \multicolumn{2}{|c|}{$1467 \mathrm{c}$} & & \\
\hline $\mathrm{TH}-069$ & \multicolumn{2}{|c|}{$1710 \mathrm{~b}$} & $0.79 \mathrm{~A}$ & $0.77 \mathrm{~B}$ \\
\hline $\mathrm{TH}-116$ & \multicolumn{2}{|c|}{$1537 \mathrm{c}$} & & \\
\hline $\mathrm{TH}-127$ & \multicolumn{2}{|c|}{$2007 \mathrm{a}$} & & \\
\hline
\end{tabular}

Regarding fluorescence initial and maximum, differences were observed among the studied hybrids, and CSM x ARGC - 019 achieved the highest mean values for this variable (Table 4), reflecting a higher photoactive energy harnessing, referenced by the carbon assimilation increase observed in the gas exchange (Table 3). For CSM x
(RL x PT) - 040, TH - 116 and TH - 069 hybrids, the lowest fluorescence mean values were observed (Table 4).

Water salinity reduced photosystem II quantum efficiency after 30 days of treatment in citrus hybrids, with a $1.6 \%$ reduction in photosystem II activity at high salinity compared to the $0.3 \mathrm{dS} \mathrm{m}^{-1}$ 
level, indicating the beginning of impairment of physiological activity by salt stress (Table 4 )..

\section{Dry biomatter formation}

With regard to dry biomass of roots, higher values were observed under low salinity for all genotypes, however, in the CSM x ARGC - 019 hybrid under salinity, a decrease of $38.4 \%$ was observed in dry mass of roots, and salinity also caused a reduction of $63.6 \%$ in $\mathrm{TH}-127$ and $60.0 \%$ in $\mathrm{TH}-116$, which were the genotypes most sensitive to water salinity (Table 5). In CSM x (RL $\mathrm{x}$ PT) -040 and $\mathrm{TH}-069$ the reduction in root dry matter was of the order of $8.7 \%$ and $10.7 \%$, respectively (Table 5), however these values show non-significant effect.

Regarding dry matter of the shoot, the highest values were observed in CSM x ARGC 019, however, when the water salinity was increased occurred reductions of order of $36.1 \%$ (Table 5).
Yet, for CSM x (RL x PT) - 040 an increase of $16.9 \%$ was observed in dry mass of aerial parts when the results obtained in levels of 0.3 and $4.0 \mathrm{dS}$ $\mathrm{m}^{-1}$ were compared, confirming that this is a genotype tolerant to salinity during seedling stage.

The total dry matter allows an overview of the plant biomass formation, as it is possible to verify coherence with its components. The highest values were observed in CSM x ARGC - 019, but, when subjected to saline water (Table 5) a reduction of $36.1 \%$ was observed in relation to solution prepared with tap water $\left(\mathrm{EC}=0.3 \mathrm{dS} \mathrm{m}^{-1}\right)$. However, as observed in the dry mass of roots, there were higher reductions with increased salinity in $\mathrm{TH}$ 116, TH - 127 and CSM x ARGC - 019 hybrids, of the order of $47.4 \%, 37.5 \%$ and $36.6 \%$, respectively, indicating that, although the CSM x ARGC - 019 had growth potential under saline conditions, it is still a genotype sensitive to salinity.

Table 5. Initial fluorescence (Fo), maximum fluorescence (Fm), variable fluorescence (Fm-Fo), photosystem II quantum efficiency $(\mathrm{Fv} / \mathrm{Fm})$, root dry matter (RDM), shoot dry matter (SDM), total dry matter (TDM) and root/shoot ratio (RSR) for different citrus genotypes grown in two levels of water salinity.

\begin{tabular}{|c|c|c|c|c|}
\hline \multirow{2}{*}{ Genotypes } & \multicolumn{4}{|c|}{ Water salinity $\left(\mathrm{dS} \mathrm{m} \mathrm{m}^{-1}\right)$} \\
\hline & $\mathrm{S} 1\left(2.6 \mathrm{dS} \mathrm{m}^{-1}\right)$ & $\mathrm{S} 2\left(6.3 \mathrm{dS} \mathrm{m}^{-1}\right)$ & $\mathrm{S} 1\left(2.6 \mathrm{dS} \mathrm{m}^{-1}\right)$ & $\mathrm{S} 2\left(6.3 \mathrm{dS} \mathrm{m}^{-1}\right)$ \\
\hline & \multicolumn{2}{|c|}{ RDM $(\mathrm{g})^{*}$} & \multicolumn{2}{|c|}{ SDM $(\mathrm{g})^{*}$} \\
\hline CSM x ARGC - 019 & $0.73 \mathrm{aA}$ & $0.45 \mathrm{aB}$ & $3.63 \mathrm{aA}$ & $2.32 \mathrm{aB}$ \\
\hline $\operatorname{CSM} \times(R L \times P T)-040$ & $0.23 \mathrm{cA}$ & $0.21 \mathrm{bA}$ & $0.53 \mathrm{bA}$ & $0.62 \mathrm{bA}$ \\
\hline $\mathrm{TH}-069$ & $0.28 \mathrm{cA}$ & $025 \mathrm{bA}$ & $0.69 \mathrm{bA}$ & $0.48 \mathrm{bA}$ \\
\hline $\mathrm{TH}-116$ & $0.40 \mathrm{bA}$ & $0.16 \mathrm{bB}$ & $0.74 \mathrm{bA}$ & $0.44 \mathrm{bA}$ \\
\hline \multirow[t]{2}{*}{$\mathrm{TH}-127$} & $0.22 \mathrm{cA}$ & $0.08 \mathrm{cB}$ & $0.58 \mathrm{bA}$ & $0.48 \mathrm{bA}$ \\
\hline & \multicolumn{2}{|c|}{$\mathrm{TDM}(\mathrm{g}) *$} & \multicolumn{2}{|c|}{ RSR* } \\
\hline CSM x ARGC - 019 & $4.36 \mathrm{aA}$ & $2.77 \mathrm{bB}$ & $0.21 \mathrm{bA}$ & $0.19 \mathrm{bA}$ \\
\hline CSM x (RL x PT $)-040$ & $0.76 \mathrm{bA}$ & $0.84 \mathrm{bA}$ & $0.44 \mathrm{aA}$ & $0.34 \mathrm{aA}$ \\
\hline $\mathrm{TH}-069$ & $0.97 \mathrm{bA}$ & $0.73 \mathrm{bA}$ & $0.47 \mathrm{aA}$ & $0.51 \mathrm{aA}$ \\
\hline $\mathrm{TH}-116$ & $1.14 \mathrm{bA}$ & $0.60 \mathrm{bB}$ & $0.61 \mathrm{aA}$ & $0.36 \mathrm{aB}$ \\
\hline $\mathrm{TH}-127$ & $0.80 \mathrm{bA}$ & $0.55 \mathrm{bA}$ & $0.37 \mathrm{aA}$ & $0.16 \mathrm{bA}$ \\
\hline
\end{tabular}

$*, * *$ and $* * *=$ significant at 0.05 and 0.01 probability level, respectively. Means followed by different small letters indicate the difference between rootstocks by Skott Knott test and different capital letters indicate the difference between salinity levels by F test at 0.05 probability level. Genotypes: CSM = common 'Sunki' mandarin [Citrus sunki (Hayata) hort. ex Tanaka]; ARGC = 'Argentina' citrange [C. sinensis (L.) Osbeck x Poncirus trifoliata (L.) Raf.]; RL = 'Rangpur' lime C. limonia Osbeck; PT = Poncirus trifoliate; TH $=$ Trifoliate hybrid.

\section{DISCUSSION}

Regarding the growth rate, different behaviour was observed in genotypes (Table 2), in CSM x (RL x PT) - 040 and TH - 127 were observed increase, this responses may be due to different mechanisms of tolerance to salinity. As explained by Esteves \& Suzuki (2008) and Taiz et al. (2015), the mechanism may be related to solute compartmentalization in vacuole, which is related to intensification of growth of aerial parts of the plant, in order to dilute and compartmentalize concentration of salts therein, such as in the situation with higher electrical conductivity, that it is possibly due to salinity hormonal stimulation function, through auxin and cytokinin, which are responsible for stimulating cell division and expansion (TAIZ et al., 2015).

On the other hand, in other genotypes reduction was observed under high salinity, which could be related to toxic ions on the roots in some rootstocks, requiring increased energy expenditure 
by root system, limiting growth potential of shoot (SILVA et al., 2014).

Among the growth variables, highlighted the stem diameter rate, being an important factor for rootstock production as it directly influences grafting time (BRITO et al., 2014), under saline conditions, the CSM x ARGC - 019 and CSM x (RL $\mathrm{x}$ PT) - 040 were able to achieve diameters between 4 and $6 \mathrm{~mm}$, which are satisfactory for grafting (SOUZA et al., 2013).

Regarding growth rates of the number of leaves, it was considered that under saline conditions, leaf production is extremely important for plant growth, since one of the most effective salt tolerance mechanisms is compartmentalisation of salts in vacuoles of old leaves, which are also responsible for gas exchange and sugar synthesis processes, enabling plant regulation and activity (MUNNS; TESTER, 2008; TAIZ et al., 2015). The increased observed can be related to mechanism of tolerance, with reduction in leaf area, for reduction in total transpiration.

The changes in the growth rates of the plants under salinity were accompanied by physiological disorders in plants, especially in more sensitive genotypes, with the example of secondary growth reduction due to differentiation and cell turgor limitations (TAIZ et al., 2015). Similar behavior was observed in citrus genotypes growth under saline conditions, by Balal et al. (2012), Rodriguez-Gamir et al. (2012), González et al. (2012) and Brito et al. (2015), indicating differences in salinity tolerance between the genotypes.

In gerenal, the lowest growth rate was observed in the genotype $\mathrm{TH}$ - 069, regardless of the salinity level, which can be associated with the characteristic of this genotype as described by Brito et al. (2012). It is also important to note that there was no salinity effect in this genotype, showing tolerance to salinity as identified by Brito et al. (2014).

Relative to growth rate, higher values were observed for CSM x (RL x PT) - 040 under nonsaline or saline water, this genotype is result of crossing between mandarin Sunki and the hybrid of Rangpur lime and Poncirus trifoliata, which were evaluated by Brito et al. (2016) who highlighted the first one as more sensitive when compared with the second one under saline stress, however, relative to these genotypes, Oliveira et al. (2015), in comparative study of the protein profiles of Sunki mandarin and Rangpur lime plants in response to water deficit, being the water stress a component of the saline stress, it was verified that acclimatization to water deficit involved specific responses that differed between Rangpur lime and 'Sunki' mandarin, which can be enhanced by the crossing between the genotypes, like in this work.

In the same line, Hussain et al. (2015) highlight that the response from genotypes used as rootstocks under saline stress is variable due to genetic origin, being genotypes from mandarin had better growth and tend to accumulate more content of ions such as sodium and chloride in the leaves, contributing to the hypothesis raised in this paper, where the highest growth rate was observed in the hybrid CSM x (RL x PT) - 040 under non-saline and saline water, that was relative to tolerance mechanism to saline stress, which can be confirmed from the gas exchange data.

Regarding gas exchange, under high salinity no changes were observed in the stomatal conductance (gs) and transpiration (E) of the CSM x (RL x PT) - 040 and the other genotypes, these variables are related to the $\mathrm{CO}_{2}$ entrace (SHIMAZAKI et al., 2007; RODRIGUEZ-GAMIR et al., 2012; SILVA et al., 2014), therefore, it indicates that plant growth reductions were due to non-stomatal factors.

Carbon dioxide absorption by gas exchange processes promotes water loss to the environment; with a reduction of water loss, $\mathrm{CO}_{2}$ entry into the mesophyll is restricted (SHIMAZAKI et al., 2007). This phenomenon is explained by water use efficiency expressed as the relation between photosynthesis and transpiration, in which values relate the carbon amount fixed by the plant per water unit (TAIZ et al., 2015) but, in all genotypes no significant effect was observed of high salinity solution.

The highest water use efficiency values were observed for the genotypes TH - 069 and CSM X ARGC - 019 (Table 3), thus characterizing the highest $\mathrm{CO}_{2}$ absorption per water unit. This is important in arid and semiarid regions with water restrictions, such as the Brazilian northeast, which faces quantitative and qualitative water shortages (SÁ et al., 2016). Thus, plants with a higher potential to use this resource are more suited to these regions.

The increase in $\mathrm{CO}_{2}$ internal concentration (Ci), associated with a reduced assimilation, indicates low ribulose-1.5-bisphosphate carboxylase-oxygenase (rubisco) activity (Machado et al., 2010; Silva et al., 2014) or damage to the photosynthetic apparatus by salt stress. Taiz et al. (2015) showed that high $\mathrm{Ci}$ increases inside leaves indicate that $\mathrm{CO}_{2}$ is not being used for sugar synthesis, suggesting that some non-stomatal factor interferes with this process. 
Some authors, for instance Syvertsen \& Garcia-Sanchez (2014) and Taiz et al. (2015), point out that some materials have the ability to compartmentalize salts in vacuoles of old leaves as salt tolerance strategies. This requires these materials to have high growth potential or, in other words, the high photosynthetic capacity. Thus, an increase in this hybrid's photosynthetic activity may be related to this mechanism of tolerance.

The increase in $\mathrm{CO}_{2}$ assimilation rate observed in CSM x ARGC - 019 corroborated with the increase in carboxylation instantaneous efficiency. However, no significant salinity effect was observed for internal $\mathrm{CO}_{2}$ concentration or stomatal conductance (Table 3), which is possibly due to the tolerance mechanism of increasing photosynthetic efficiency, which was also observed in carboxylation instantaneous efficiency (Table 3).

Similarly, Hussain et al. (2015) found the higher value of assimilation rate in more tolerant genotypes, highlighting genotypes from mandarin as parents, in this genotype the authors correlated the reduction in levels of toxic ions in the leaves due to process of detoxification when the plants, possibly, to get rid of the leaves that accumulated high contents of toxic ions $\left(\mathrm{Cl}^{-}\right)$and at the end produced new leaves to maintain photosynthesis and plant growth.

Another physiological aspect that can be used to explain the effect of salinity is the chlorophyll fluorescence, composed by the initial, maximum, variable fluorescence and the efficiency of photosystem II. For Baker \& Rosenqust (2004), initial fluorescence explains fluorescence when the photosystem II (PSII) primary electron-receiving quinone (QA) is fully oxidised and the reaction centre (P680) is open, indicating photochemical reaction activation and maximum fluorescence, this, in turn, explains the state why PSII reaction centres are unable to increase photochemical reactions and fluorescence reaches its maximum capacity, proving the reduced condition of all quinone (QA) by transferred electrons from the P680 centre.

The initial fluorescence increase indicates destruction of the PSII reaction centre (P680), or decrease in the antenna excitation energy transfer capability to PSII (BAKER; ROSENQVST, 2004). Thus, it can be assumed that due to central reaction damage, evidenced by the initial fluorescence increase, the observed maximum fluorescence increase can be related to the species' tolerance mechanism, seeking to compensate for the energy loss and to perform its maximum photosynthetic potential, this fact was observed by the increase in net assimilation rate of this hybrid, which was verified in the gas exchange study (Table 3 ).

In this line, the $\mathrm{TH}-069$ had the highest assimilation rate (Table 3), which can be directly related to the physiology efficiency of this hybrid in obtaining a high photosynthetic yield with low consumption of resources, since the salinity, even limiting the water availability, did not affect the chlorophyll fluorescence of this genotype (Tables 3 and 4). This is a very important factor in regions facing environmental constraints, such as water, in the semiarid regions in northeastern Brazil (MEDEIROS et al., 2003).

Photosystem II quantum efficiency is a widely used variable in the detection of photosynthetic activity disturbance under environmental stress, and its reduction promotes restrictions in this process (SILVA et al., 2014). However, even with reduction, the observed values (0.77) were above the impairment range $(\mathrm{Fv} / \mathrm{Fm}<$ 0.75) described by Baker \& Rosenqvst (2004).

All values of Photosystem II quantum efficiency were above 0.75 in all genotypes under higher or low saline solution, thus it was observed that no significative damage occured in photossintetic apparatus, even for genotype CSM x (RL x PT) - 040, where an increase was noted in values of minimum and maximum fluorescence (Table 4), it was observed as tolerant, being this affirmation confirmed from data of relative growth rate and gas exchange, similar to observed by Brito et al. (2015), that show the CSM x (RL x PT) - 040 tolerant to water with EC until $2.4 \mathrm{dS} \mathrm{m}^{-1}$ when grafted with 'Star Rubi' grapefruit. Results which may be related to the cross between a mandarin and Rangpur lime, which have the potential tolerance (HUSSAIN et al., 2015; BRITO et al., 2016).

Such changes in growth, caused by reductions in gas exchange and chlorophyll fluorescence, reflected in the reduction in dry mass formation of the plants which, according with Sá et al. (2013), can be related to plant's defence mechanisms such as reducing the absorption of toxic ions, ensuring higher and longer resistance to salt stress. Increased salt absorption can cause, in addition to toxicity, nutritional disorders in plants (BALAL et al. 2012; GONZÁLEZ et al. 2012; SYVERTSEN; GARCIA-SANCHEZ, 2014).

According to Ayers e Westcot (1985), when a certain salinity level causes small changes in growth and physiological aspects (a reduction of equal or less than $10 \%$ ), such as observed for CSM $\mathrm{x}(\mathrm{RL} \times \mathrm{PT})$ - 040 and $\mathrm{TH}-069$, the genotypes could be classified as tolerant to salinity, this information is important for plant breeding 
programs and the production systems which require the use of saline water.

However, in the genotypes CSM x ARGC 019 e no TR - 116 reductions were observed more than $10 \%$, which is relative to salinity effect, such as nutritional and physiological imbalance, which directly influences assimilated carbon conversion by plants, promoting reductions in crops' biomass accumulation (TAIZ et al., 2015), which is evident in the most sensitive genotypes.

On the other hand, the CSM x (RL x PT) 040 and $\mathrm{TH}$ - 069 hybrids, even though with less growth potential, had higher salinity tolerance, according to the absence of mass reduction in roots or shoots. In these genotypes it may be inferred that crosses between mandarin, Rangpur lime and Poncirus trifoliata allowed the expression of genes that induced tolerance to salt stress, however it should be confirmed in other stages of the citrus crop production system, including genetic and biochemical data. Thus, yhere is possibility to have genotypes recomended for citrus production system under saline conditions, some parents, for instance, the Cleopatra mandarin (C. reshni Hort. Ex Tan) considered a rootstock tolerant to salinity (Maas, 1993).

The root/shoot ratio values, in all genotypes and water salinity levels, were less than one, indicating that there is a shoot prioritization over the root system. However, it should be noted that an increase in salt concentration caused significant reduction of this ratio only on genotype $\mathrm{TH}-116$ (Table 5). Such differentiation may be related to different tolerance mechanisms, where the reduced rate can be interpreted by the need for shoot cell tissue in order to accumulate salt in the vacuoles, and the increased ratio can be attributed to salt absorption reduction through the root system by ion selection, forcing more substrate volume exploitation by the roots, this favours less salt uptake and dilution in the aerial part (MUNNS; TESTER 2008). Regarding the reduction, Sá et al. (2013) and Sá et al., 2016 found similar responses in papaya cultivars irrigated with saline water, with limited root development due to increased salinity, directly reflecting seedling root/shoot ratios.

\section{CONCLUSIONS}

The genotypes CSM x (RL x PT) - 040, CSM x ARGC - 019 and TH - 069 showed the high tolerance to saline solution, based in dry matter relative reduction; $\mathrm{TH}-116$ and $\mathrm{TH}-127$ genotypes were more sensitive to saline solution.

The genotypes CSM x ARGC - 019, CSM x (RL x PT) - 040 and TH - 069 had the highest physiological potential under saline conditions. The hybrid CSM x ARGC - 019 showed best growth rates, whereas $\mathrm{TH}$ - 069 has characteristics of small growth.

\section{ACKNOWLEDGEMENTS}

To CNPq, Brazilian National Council of Scientific and Technological Development, and Embrapa Cassava \& Fruits.

RESUMO: Altas concentrações de sais no solo e na água são comuns em regiões semiáridas, o que reduz o crescimento e o desenvolvimento das culturas, notadamente as sensíveis, como os citros, sendo importante a identificação de materiais tolerantes assim como o estudo da fisiologia destes. Assim, realizou-se um experimento para avaliar o crescimento e a fisiologia de híbridos de Poncirus trifoliata durante a formação de porta-enxertos sob condições de estresse salino. O experimento foi realizado usando um esquema factorial, 2 x 5, correspondendo a dois níveis de salinidade na solução nutritiva $\left(2,6\right.$ e $\left.6,3 \mathrm{dS} \mathrm{m}^{-1}\right)$ e cinco híbridos de citros. Tais híbridos foram obtidos a partir do programa de melhoramento genético de citros da Embrapa Mandioca e Fruticultura, PMG - Citrus, a saber: tangerineira 'Sunki Comum' x citrange 'Argentina' - 019; tangerineira 'Sunki Comum' x (limoeiro 'Cravo' x Poncirus trifoliata) 040 e os híbrido trifoliados - 069, 116 e 127. Os tratamentos foram distribuídos em delineamento experimental de blocos ao acaso, com três repetições. As plantas de origem nucelar dos genótipos foram cultivadas em sistema hidropônico por meio de vasos de Leonard. A aplicação das soluções nutritivas com águas salinas começaram aos 90 dias após a semeadura, se extendendo até os 120 dias, quando as plantas foram avaliadas em relação ao crescimento e a fisiologia. Os genótipos tangerineira 'Sunki Comum' x citrange 'Argentina' - -19, tangerineira Sunki Comum x x (limoeiro 'Cravo' x Poncirus trifoliata) - 040 e o híbrido trifoliado - 069 tiveram maior tolerância à salinidade, enquanto os híbridos trifoliados 116 e 127 foram os menos tolerantes.

PALAVRAS-CHAVE: Citrus spp. Fluorescência da clorofila. Salinidade. 


\section{REFERENCES}

AYERS, R. S.; WESTCOT, D. W. Water quality for agriculture. FAO, Irrigation and Drainage Paper, 29, $1985,174 \mathrm{p}$.

BAKER, N. R.; ROSENQVST, E. Applications of chlorophyll fluorescence can improve crop production strategies: An examination of future possibilities. Journal of Experimental Botany, v. 55, n. 403, p. 16071621, 2004. http://dx.doi.org/10.1093/jxb/erh196.

BALAL, R. M.; KHAN, M. M.; SHAHID, M. A.; MATTSON, N. S.; ABBAS, T.; ASHFAQ, M.; GARCIASANCHEZ, F.; GHAZANFER. U.; GIMENO, V.; IQBAL, Z. Comparative studies on the physiobiochemical, enzymatic, and ionic modifications in salt-tolerant and salt-sensitive citrus rootstocks under $\mathrm{NaCl}$ stress.

Journal of the American Society for Horticultural Science, v. 137, n. 2, p. 86-95, 2012.

BENINCASA, M. M. P. Análise de crescimento de plantas: Básico. Jaboticabal: Fundação de apoio a pesquisa, ensino e extensão de São Paulo, 2003, 41p.

BRITO, M. E. B.; BRITO, K. S. A.; FERNADES, P. D.; GHEYI, H. R.; SUASSUNA, J. F.; SOARES FILHO, W. S.; MELO, A. S. XAVIER, D. A. Growth of ungrafted and grafted citrus rootstocks under saline water irrigation. African Journal of Agricultural Research, v. 9, n. 50, p. 3600-3609, 2014.

http://dx.doi.org/10.5897/2014.9039

BRITO, M. E. B.; SÁ, F. V. S.; SOARES FILHO, W. S.; SILVA, L. A.; FERNANDES, P. D. Gas exchange and fluorescence of citrus rootstocks varieties under saline stress. Revista Brasileira de Fruticultura, v. 38, n. 2, e-951, 2016. http://dx.doi.org/10.1590/0100-29452016951

BRITO, M. E. B.; SILVA, E. C. B.; FERNANDES, P. D.; SOARES FILHO, W.S.; COELHO FILHO, M. A.; SÁ, F. V. S.; MELO, A. S.; BARBOSA, R. C. A. Salt balance in the substrate and growth under salt stress of seedlings of tahiti acid lime grafted onto sunki mandarin hybrids. Australian Journal of Crop Science, v. 9, p. 954-961, 2015.

BRITO, M. E. B.; SOARES, L. A. A.; FERNANDES, P. D.; LIMA, G. S.; SÁ, F. V. S.; MELO, A. S. Physiological behavior of scion/rootstock combination of citrus under water stress. Brazilian Journal of Agricultural Science, v. 7, n. supplement, p. 857-865, 2012. http://dx.doi.org/10.5039/agraria.v7isa1941

ESTEVES, B. S.; SUZUKI, M. S. Plants under effect of salinity. Oecologia Australis. v. 12, n. 4, p. 662-679, 2008.

FERREIRA, D. F. Sisvar: A computer statistical analysis system. Ciência e Agrotecnologia, v. 35, n. 6, p. 1039-1042, 2011. http://dx.doi.org/10.1590/S1413-70542011000600001

GONZÁLEZ, P.; SYVERTSEN, J. P.; Etxeberria, E. Sodium distribution in salt-stressed citrus rootstock seedlings. Hortscience, v. 47, n. 10, p. 1504-1511, 2012.

HOAGLAND, D. R.; ARNON, D. I. The water-culture method for growing plants without soil. Berkeley: California Agricultural Experiment Station, 1950. 32p.

HUSSAIN, S.; MORILLON, R.; ANJUM, M. A.; OLLITRAULT, P.; COSTANTINO, G.; LURO, F. Genetic diversity revealed by physiological behavior of citrus genotypes subjected to salt stress. Acta Physiologiae Plantarum, v. 37, s.n, p. 1740 - 1750, 2015. http://dx.doi.org/10.1007/s11738-014-1740-4

MAAS, E. V. Salinity and citriculture. Tree Physiology, v. 12, n. 2, p. 195-216, 1993. 
MACHADO, D. F. S. P.; MACHADO, E. C.; MACHADO, R. S.; RIBEIRO, R. V. Effects of low night temperature and rootstocks on diurnal variation of leaf gas exchange rates and photochemical activity of 'Valência' sweet orange plants. Revista Brasileira de Fruticultura, v. 32, n. 2, p. 351-35, 2010. http://dx.doi.org/10.1590/S0100-29452010005000064

MEDEIROS, J. F.; LISBOA, R. A.; OLIVEIRA, M.; SILVA JÚNIOR, M. J.; ALVES, L. P. Characterization of the groundwater used for irrigation in the melon producing area of the Apodi Plateau. Revista Brasileira de Engenharia Agricola e Ambiental, v. 7, n. 3, p. 469-472, 2003. http://dx.doi.org/10.1590/S141543662003000300010

MUNNS, R.; TESTER, M. Mechanism of salinity tolerance. Annual Review of Plant Biology, v. 59, s.n, p. 651-681, 2008. 10.1146/annurev.arplant.59.032607.092911

OLIVEIRA, T. M.; SILVA, F. R.; BONATTO, D.; NEVES, D. M.; MORILLON, R.; MASERTI, B. E.; COELHO FILHO, M. A.; COSTA, M. G. C.; PIROVANI, C. P.; GESTEIRA, A. S. Comparative study of the protein profiles of Sunki mandarin and Rangpur lime plants in response to water deficit. BMC Plant Biology, v. 15, s.n, p. 69-85, 2015. http://dx.doi.org/10.1186/s12870-015-0416-6

PEREZ-PEREZ, J. G.; GARCIA-SANCHEZ, F.; ROBLES, J. M.; BOTÍA, P. ‘Star Ruby’ grapefruit and 'Clemenules' mandarin trees show different physiological and agronomic responses to irrigation with saline water. Irrigation Science, v. 33, n. 3, p. 191-204, 2015. http://dx.doi.org/10.1007/s00271-014-0459-8

QADIR, M.; OSTER, J. D.; SCHUBERT, S.; NOBLE, A. D.; SAHRAWAT, K. L. Phytoremediation of sodic and saline-sodic soils. Advances in Agronomy, v. 96, s.n, p. 197-247, 2007. http://dx.doi.org/10.1016/S00652113(07)96006-X

RODRIGUEZ-GAMIR, J.; ANCILLO, G.; LEGAZ, F.; PRIMO-MILLO, E.; FORNER-GINER, M. A. Influence of salinity on pip gene expression in citrus roots and its relationship with root hydraulic conductance, transpiration and chloride exclusion from leaves. Environmental and Experimental Botany, v. 78, s.n, p. 163-166, 2012. http://dx.doi.org/10.1016/j.envexpbot.2011.12.027

SÁ, F. V. S.; BRITO, M. E. B.; MELO, A. S.; ANTÔNIO NETO, P.; FERNANDES, P. D.; FERREIRA, I. B. Production of papaya seedlings irrigated with saline water. Revista Brasileira de Engenharia Agrícola e Ambiental, v. 17, n. 10, p. 1047-1054, 2013. http://dx.doi.org/10.1590/S1415-43662013001000004

SÁ, F. V. S.; BRITO, M. E. B.; SILVA, L. A.; MOREIRA, R. C. L.; FERNANDES, P. D.; FIGUEIREDO, L. C. Physiology of perception of saline stress in 'Common Sunki' mandarin hybrids under saline hydroponic solution. Comunicata Scientiae, v. 6, n. 4, p. 463-470, 2015. http:// dx.doi.org/10.14295/ CS.v6i4.1121

SÁ, F. V. S.; BRITO, M. E. B.; MOREIRA, R. C. L.; MELO, A. S. DE; SILVA, L. A.; GHEYI, H. R.; FIGUEIREDO, L. C.; PAIVA, E. P. de. Balance of salts and growth of papaya cultivars irrigated with saline water. Bioscience journal, v. 32, n. 4, p. 849-856, 2016.

SHIMAZAKI, K. I.; DOI, M.; ASMANN, S. M.; KINOSHITA, T. Light regulation of stomatal movement. Annual Review of Plant Biology, v. 58, s.n, p. 219 - 247, 2007. 10.1146/annurev.arplant. 57.032905.105434

SILVA, L. A.; BRITO, M. E. B.; SÁ, F. V. S.; MOREIRA, R. C. L.; SOARES FILHO, W. S.; FERNANDES, P. D.; Physiological mechanisms in citrus hybrids under saline stress in hydroponic system. Revista Brasileira de Engenharia Agricola e Ambiental, v. 18, n. supplement, p. S1-S7, 2014.

SINGH, A.; SAINI, M. L.; BEHL, R. K. Screening of citrus rootstocks for salt tolerance in semi-arid climates A review. Tropics, v. 13, n. 1, p. 53-66, 2003. 
SOUZA, A. G.; FAQUIN, V.; CHALFUN, N. N.; SOUZA, A. A. Production of Ponkan tangerine seedlings in a hydroponic system. Revista Ciência Agronômica, v. 44, n. 4, p. 902-909, 2013. http://dx.doi.org/10.1590/ S1806-66902013000400029.

SYVERTSEN, J. P.; GARCIA-SANCHEZ, F. Multiple abiotic stresses occurring with salinity stress in citrus. Environmental and Experimental Botany, v. 103, s.n, p. 128-137, 2014.

http://dx.doi.org/10.1016/j.envexpbot.2013.09.015

TAIZ L, ZEIGER E, MOLLER, IM, MURPHY, A. Plant physiology. 6.ed. Sinauer Associates, 2015. 761 p. 